\title{
Antibiotic Resistance in Bacterial Isolates from Commercial Probiotics Used in Aquaculture
}

\author{
A. Uma* and G. Rebecca
}

\begin{abstract}
State Referral Laboratory for Aquatic Animal Health, Tamil Nadu Fisheries UniversityMadhavaram Campus, Madhavaram Milk Colony, Chennai-600051, Tamil Nadu, India
\end{abstract}

*Corresponding author

\begin{abstract}
A B S T R A C T
Aquaculture involves farming of commercially important species of finfish and shellfish. Intensification of aquaculture practices has led to many diseases of commercial importance. Probiotics are beneficial microorganisms used in aquaculture to improve the

Keywords

Probiotics, Aquaculture, Antibiotic resistance, Antibiotic resistant genes

Article Info

Accepted:

14 December 2017

Available Online:

10 January 2018 health and disease resistance of the cultured fish. It is considered as a safe alternative to antibiotics which confer resistance in the microbes when used indiscriminately. In the present study, bacterial isolates (PB-1, PB-2, PB-3, PB-4 and PB-5) from the selected commercial probiotic products used in aquaculture were assessed for their bacterial pathogen inhibition efficiency, antibiotic sensitivity and the presence of antibiotic resistance genes viz., tet $\mathrm{K}$, tet $\mathrm{L}$, tet $\mathrm{M}$ and tet $\mathrm{O}$. The probiotic isolates exhibited varying levels of inhibition against the bacterial pathogens viz., Aeromonas hydrophila, Streptococcus sp., Flavobacterium columnare, Edwarsiella tarda and Vibrio alginolyticus. F.columnare was the most inhibited by all the five probiotic bacterial isolates. The antimicrobial sensitivity test showed that the isolates, PB-2, PB-3, PB-4 and PB-5 were resistant to oxytetracycline except the isolate, $\mathrm{PB}-1$. The antibiotic resistant genes, tet $\mathrm{K}$ and tet $\mathrm{L}$ were found to be present in all the probiotic bacterial isolates, whereas tet $\mathrm{M}$ and tet $\mathrm{O}$ were absent in all the isolates. The results of the study showed that although probiotics exhibit inhibitory activity against the bacterial pathogens, antibiotic resistance to oxytetracycline and the presence of antibiotic resistant genes showed that they could also act as a possible source for the transfer and spread of antibiotic resistance among the microbes in the aquatic ecosystem.
\end{abstract}

\section{Introduction}

Aquaculture which involves the farming of commercially important fin fish and shell fish contributes to the cheap and nutritious fish protein production (Uddin et al., 2015). In aquaculture, a wide range of antimicrobials are being used for the control of diseases (Rodgers and Furones, 2009). Intensification of aquaculture practices has led to the development of various diseases caused due to pathogens and water quality issues (Bondad $e t$ al., 2005). The use of antibiotics for the control of bacterial diseases in aquaculture has been proven unsustainable and ineffective due to development of antibiotic resistance in pathogens (Cabello, 2006) which may spread to other microbes through horizontal gene 
transfer via plasmids and other genetic elements of cultured fish and humans (Moriarty, 1996; Holmstrom et al., 2003). Probiotics are used in aquaculture for the degradation of organic matter which reduces the sludge and slime formation, resulting in improved water quality and reduced incidence of diseases (Rajinikanth et al., 2010) and to improve the gut health in fishes (Ige, 2013). An ideal probiotics need to be effective over a range of temperatures extremes and variations in salinity (Fuller, 1989) and suppress the growth of pathogens (Parker, 1974). Although the beneficial effects of probiotics have been documented by various researchers, recent studies have revealed the presence and expression of antibiotic resistant genes in the probiotics used in foods and aquaculture (Gryczan et al., 1984; Hummel et al., 2007 and Wong et al., 2015). As probiotics are being widely used in aquaculture operations, knowledge on how effectively they control of the bacterial pathogens, their sensitivity to the antibiotics used in the treatment of bacterial diseases in aquaculture and the presence of the antibiotic resistant genes is essential. Hence, this study was undertaken with an objective to study the bacterial inhibition efficiency, antibiotic sensitivity and the presence of antibiotic resistant genes in the bacterial isolates from the selected commercial probiotic products.

\section{Materials and Methods}

\section{Bacterial strains and culture conditions}

Samples of probiotic products were collected from the fish and shrimp farms in Tamil Nadu and Andhra Pradesh, India. Five different probiotics products were selected randomly and the bacterial strains were isolated from the products following spread plating method on tryptic soya agar (TSA) with and without salt $(1 \%)$. The individual colonies were subcultured, purified and five isolates were randomly selected, one representative isolate from each probiotic product, coded as PB-1, PB-2, PB-3, PB-4 and PB-5 and used for the study. The confirmed isolates of bacterial pathogens viz., Aeromonas hydrophila, Streptococcus sp., Edwardsiella tarda, Flavobacterium columnare, Vibrio alginolyticus from the culture collection of State referral laboratory for aquatic animal health, Tamilnadu Fisheries University or ATCC were used to study the bacterial inhibitory activity of the probiotics isolates. The young cultures of the bacterial pathogens grown in tryptic soy broth (TSB) with or without $\mathrm{NaCl}$ or Brain heart infusion (BHI) broth were used. The probiotic isolates were serially diluted, spread plated on TSA and the pre-grown suspension of the bacterial pathogens $(10 \mu \mathrm{l})$ were spotted on the plates, allowed to absorb and incubated at $37^{\circ} \mathrm{C}$ for 24 to $48 \mathrm{~h}$ and the observations were recorded.

\section{Antibiogram of the probiotics isolates}

Sensitivity of the probiotics bacterial isolates (PB-1, PB-2, PB-3, PB-4 and PB-5) to oxytetracycline (OTC) was assessed by agar disc diffusion technique on Mueller Hinton agar (Bouer et al., 1966). The agar plates were incubated at $35 \pm 2^{\circ} \mathrm{C}$ for $24 \mathrm{~h}$ and the diameter of zone of inhibition $(\mathrm{mm})$ was measured. Sensitivity to oxytetracycline was assessed based on the zone size interpretation chart (CLSI, 2012).

\section{PCR detection of resistant genes}

The presence of antibiotic resistant genes in the probiotics isolates PB-1, PB-2, PB-3, PB-4 and PB-5 were screened by PCR. The targeted genes include tetracycline efflux proteins viz., tet $\mathrm{K}$ and $t e t \mathrm{~L}$, ribosomal protection proteins $v i z$, tet $\mathrm{M}$ and tet $\mathrm{O}$. DNA was extracted using a commercial DNA extraction kit (Qiagen, Germany) from the probiotic bacterial isolates. PCR screening for tet $\mathrm{K}$, tet $\mathrm{L}$, tet $\mathrm{M}$ and $t e t \mathrm{O}$ 
was carried out following the published protocols (Table 1). The PCR products were analysed on a $1.5 \%$ agarose gel containing 0.5 $\mu \mathrm{g} / \mathrm{mL}$ ethidium bromide in $1 \mathrm{x}$ Tris-borateEDTA (TBE) buffer and visualized under a UV transilluminator.

\section{Results and Discussion}

Assessment of the bacterial pathogen inhibitory activity of the probiotic isolates PB1, PB-2, PB-3, PB-4 and PB-5 showed that isolates $\mathrm{PB}-3$ and $\mathrm{PB}-5$ possess the highest inhibitory activity against $F$. columnare and $V$. alginolyticus. $F$. columnare was the most inhibited by all the five probiotic isolates. Whereas, E. tarda was the most resistant or the least inhibited by the probiotic isolates (Fig. 1 and Table 2). Antibiogram for the probiotic isolates against oxytetracyline showed that the isolate PB-1 alone was intermediately sensitive and the other isolates PB-2, PB-3, PB-4 and PB-5 were resistant to oxytetracycline. All the five probiotic bacterial isolates were observed to carry the antibiotic resistant genes coding for tetracycline efflux proteins viz., tet $\mathrm{K}$ and tet $\mathrm{L}$. However, tet $\mathrm{M}$ and tet $\mathrm{O}$ genes, which are involved in the bacterial ribosomal protection were absent in the probiotics bacterial isolates (Fig. 2).

In aquaculture, use of probiotics confer beneficial effects to the cultured species by reducing stress caused due to various biotic and abiotic factors in poor environment conditions, unbalanced nutrition (Kautsky et al., 2000). In recent decades, prevention and control of animal diseases has focused on the use of chemicals and antibiotics, which generate significant risks to public health by promoting the selection, propagation, and persistence of bacterial-resistant strains (FAO,2006 and WHO, 2012). Probiotics are considered as safe and viable alternatives for the health management for improved production in aquaculture (Martinez et al.,
2012). Recent studies have shown the presence of genes that confer antibiotic resistance thereby posing a danger of transmission of such genes to pathogenic bacteria through horizontal gene transfer (Imperial et al., 2016). Tetracycline resistant genes viz., tet $\mathrm{K}$, tet $\mathrm{L}$ tet $\mathrm{M}$, tet $\mathrm{O}$ associated with tetracycline resistance have been reported in bacterial isolates. The tet $\mathrm{K}$ and tet $\mathrm{L}$ genes code for efflux proteins, which prevent tetracycline from accumulating within the cell tet $\mathrm{M}$ and tet $\mathrm{O}$ code for ribosomal protection proteins, which reduce the affinity of tetracycline to the ribosome (Ullah et al., 2012). The presence of tetracycline resistant genes (Uddin et al., 2015) and the genetic determinants conferring resistance to aminoglycosides, erythromycin, tetracycline tet $\mathrm{K}$, tet $\mathrm{L}$ and $t e t \mathrm{M}$, and lincosamides $\ln u(\mathrm{~A})$ and $\ln u(\mathrm{~B})$ have been documented in the probiotics bacterial isolates (Munoz-Atienza et al., 2013).

The bacterial inhibitory activity against the bacterial pathogens observed in the study show that probiotics could be used for the control the bacterial diseases in fish. Various mechanisms viz., secretion of antimicrobial substances, competitive adherence to the mucosa and epithelium have been documented related to the antagonistic effects of probiotics on the microorganisms (Collado et al., 2010).

Antibiotics are widely and intensively used in aquaculture for microbial disease control and prevention, however, indiscriminate use results in the prevalence and persistence of antibiotic resistant bacteria and their resistance determinants in the environment (Dang et al., 2007). Proper regulation on the use of probiotics in aquaculture will avoid the potential risk of transfer of antibiotic resistant genes to other microbes in the culture systems and subsequently to the other microflora of shrimp that has a potential risk transfer to the consumers. 
Fig.1 Bacterial pathogen inhibition by the probiotic isolates

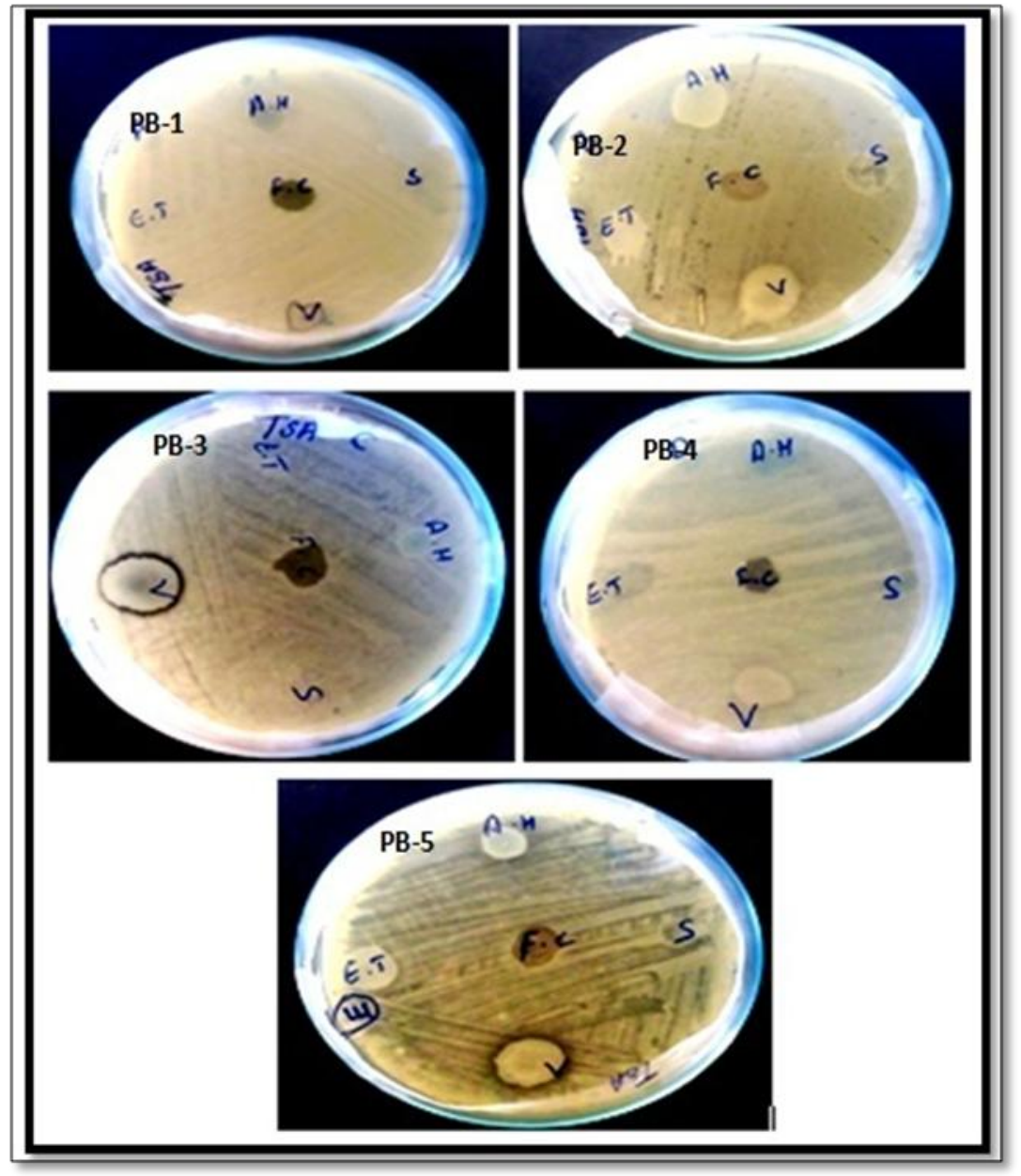

AH- Aeromonas hydrophila, S- Streptococcus sp., ET- Edwardsiella tarda, FC- Flavobacterium columnare, VVibrio alginolyticus

Fig.2 PCR amplification of the antibiotic resistant genes in the probiotic bacterial isolates

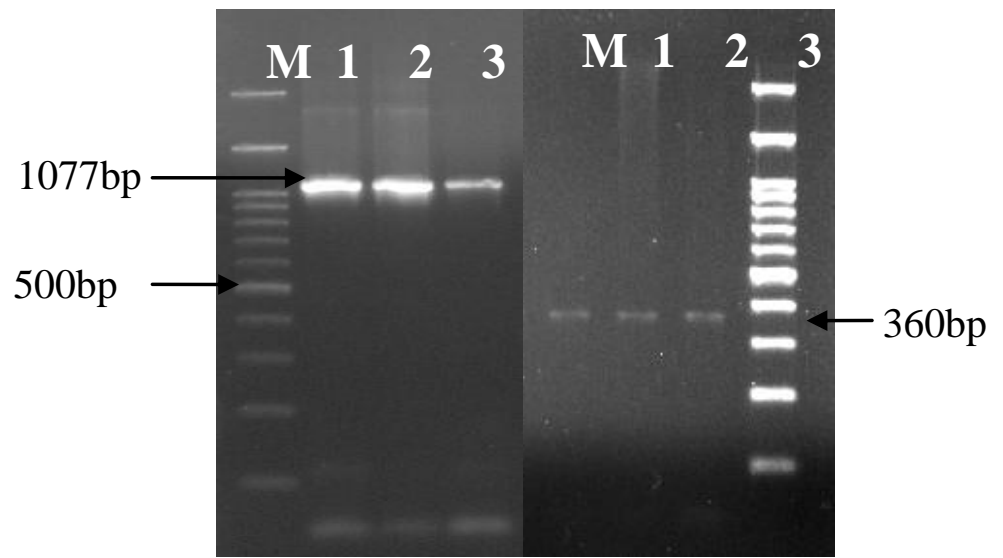

Lanes: M-100 bp molecular weight marker;1-3 PCR amplified product of tet Lene (1077 bp) and tet $\mathrm{K}$ gene (360 bp) 
Table.1 PCR primers used to study the antibiotic resistant genes in probiotics isolates

\begin{tabular}{|l|l|l|}
\multicolumn{1}{c|}{ Primer code } & \multicolumn{1}{|c}{ Primer sequence } & \multicolumn{1}{c|}{ Reference } \\
\hline tet $\mathrm{K}$ & $\begin{array}{l}\text { F-GTAGCGACAATAGGTAATAGT } \\
\text { R-GTAGTGACAATAAACCTCCTA }\end{array}$ & Strommenger et al., 2003 \\
\hline tet $\mathrm{L}$ & $\begin{array}{l}\text { F-ATAAATTGTTTCGGGTCGGTAAT } \\
\text { R-AACCAGCCAACTAATGACAAGAT }\end{array}$ & Trzcinski et al., 2000 \\
\hline tet $\mathrm{M}$ & $\begin{array}{l}\text { F-AGTTTTAGCTCATGTTGATG } \\
\text { R-TCCGACTATTTAGACGACGG }\end{array}$ & \\
\hline tet $\mathrm{O}$ & $\begin{array}{l}\text { F-AACTTAGGCATTCTGGCTCAC } \text { et } \text { al., } 2001 \\
\text { R-TCCCACTGTTCCATATCGTCA }\end{array}$ & \\
\hline
\end{tabular}

Table. 2 The level of inhibitory activity exhibited by the probiotics Isolates against bacterial pathogens

\begin{tabular}{|l|l|c|c|c|c|c|}
\hline \multirow{2}{*}{$\begin{array}{l}\text { SI. } \\
\text { No }\end{array}$} & Bacterial pathogen & \multicolumn{5}{|c|}{ Inhibitory activity by the isolates } \\
\hline 1 & Aeromonas hydrophila & PB-1 & PB-2 & PB-3 & PB-4 & PB-5 \\
\hline \hline 2 & \begin{tabular}{l} 
Streptococcus sp. \\
\hline 3
\end{tabular} & - & + & - & - & - \\
\hline 4 & $\begin{array}{l}\text { Edwardsiella tarda } \\
\text { Flavobacterium } \\
\text { columnare }\end{array}$ & - & - & - & - & + \\
\hline 5 & Vibrio alginolyticus & + & + & + & - & - \\
\hline
\end{tabular}

Probiotics are used in aquaculture to improve the water quality of the production systems and to improve gut health and immunity in the cultured fish. The result of this study has show the presence of antibiotic resistant genes like tet $\mathrm{K}$ and tet $\mathrm{L}$ in the commercial probiotics used in aquaculture which pose the danger of transfer of antibiotic resistant genes to the native microflora in the aquatic environment. Hence, it is concluded that it is important to put forth suitable regulations on the use of probiotics in aquaculture to avoid the risk of spread of antibiotics resistance in the aquatic eco systems.

\section{References}

Bauer, A.W. Kirby, W.M. Sherris, J.C. Turck, M. 1966. Antibiotic susceptibility testing by a standardized single disk method. American Journal of Clinical Pathology, 45:493-496.

Bondad-Reantaso, M.G., Subasinghe, R.P., Arthur, J.R., Ogawa, K., Chinabut, S., Adlard, R., Tan, Z., Shariff, M. 2005. Disease and health management in Asian aquaculture. Veterinary Parasitology, 132(3-4), 249-272.

Cabello, F.C. 2006. Heavy use of prophylactic antibiotics in aquaculture: a growing problem for human and animal health and for the environment. Environmental Microbiology, 8 (7), 1137-1144.

CLSI, 2012. Performance Standards for Antimicrobial Susceptibility Testing; Twenty-Second Informational Supplement. Clinical and Laboratory Standards Institute, Wayne, PA 19087, USA, CLSI document M100-S22., 32 (3). 
Collado, M.C, Gueimonde, M, Salminen, S. 2010. Probiotics in adhesion of pathogens: mechanisms of action; in Watson RR, Preedy VR (eds): Bioactive Foods in Promoting Health, Academic Press, Elsevier. 23: 353-370.

Dang. H, Zhang. X, Song. L, Chang. Y, Yang. G. 2007. Molecular determination of oxytetracycline-resistant bacteria and their resistance genes from mariculture environments of China. Journal of Applied_Microbiology. 103(6): 25802592.

FAO/OIE/WHO, 2006. Antimicrobial use in aquaculture and antimicrobial resistance, Report of a Joint. Expert consultation on antimicrobial use in aquaculture and antimicrobial resistance, Seoul, Republic of Korea., 13-16.

Fuller, R, 1989. Probiotics in man and animals. Journal of Applied Bacteriology., 6 (5), 365-378.

Gryczan, T., Israeli-Reches, M., Bue, M., Dubnau, D. 1984. DNA sequence and regulation of ermD, a macrolidelincosamide-streptogramin B resistance element from Bacillus licheniformis. Molecular and General Genetics, 194(3), 349-356.

Holmstrom K., Graslund S., Wahlstrom A., Poungshompoo S., Bengtsson B. E., Kautsky N. (2003). Antibiotic use in shrimp farming and implications for environmental impacts and human health. International Journal of Food Science and Technology. 38, 255-266.

Hummel, A.S., Hertel, C., Holzapfel, W.H., Franz, C.M. 2007. Antibiotic resistances of starter and probiotic strains of lactic acid bacteria. Applied and environmental microbiology, 73 (3), 730-739.

Ige, B.A, 2013. Probiotics use in intensive fish farming. African Journal of
Microbiology Research, 7 (22), 27012711.

Imperial, I.C., Ibana, J.A. 2016. Addressing the antibiotic resistance problem with probiotics: reducing the risk of its double-edged sword effect. Frontiers in microbiology, 7.

Kautsky, N. Ronnb, P., Tedengren, M., Troell, M. 2000. Ecosystem perspectives on management of disease in shrimp pond farming. Aquaculture, 191(1-3), 145-161.

Martinez Cruz, P., Ibáñez, A.L., Monroy Hermosillo, O.A., Ramírez Saad, H.C. 2012. Use of Probiotics in Aquaculture. ISRN Microbiology, 13.

Moriarity, D.J, 1996. Probiotics and bioremediation in aquaculture. Asian shrimp news. 26 (3), 14-17.

Munoz-Atienza, E., Gómez-Sala, B., Araújo, C., Campanero, C., Del Campo, R., Hernández, P.E., Herranz, C., Cintas, L.M. 2013. Antimicrobial activity, antibiotic susceptibility and virulence factors of lactic acid bacteria of aquatic origin intended for use as probiotics in aquaculture. BMC Microbiology, 13, 15.

Parker, R.B, 1974. Probiotics, the other half of the antibiotics story. Animal Nutrition Health, 29, 4-8.

Rajinikanth, T., Ramasamy, P., Ravi, V. 2010. Efficacy of probiotics, growth promotors and disinfectants in shrimp grow out farms. American-Eurasian Journal of Agricultural and Environmental Science, 7 (3), 347-354.

Rodgers, C.J., Furones, M.D. 2009. Antimicrobial agents in aquaculture: practice, needs and issues. Options Mediterraneennes, 86, 41-59.

Uddin, G.M.N., Larsen, M.H., Christensen, H., Aarestrup, F.M., Phu, T.M., Dalsgaard, A. 2015. Identification and antimicrobial resistance of bacteria isolated from probiotic products used in 
shrimp culture. PloS One., 10 (7), p.e0132338.

Ullah, F., Malik, S.A., Ahmed, J., Shah, S.M., Ayaz, M., Hussain, S., Khatoon, L. 2012. Investigation of the genetic basis of tetracycline resistance in Staphylococcus aureus from Pakistan. Tropical Journal of Pharmaceutical Research, 11 (6), 925-931.
WHO, 2012. Antimicrobial resistance. Fact sheet N॰194. http://www.who.int/media centre/factsheets/fs194/es/index.html.

Wong, A., Saint Ngu, D.Y., Dan, L.A., Ooi, A., Lim, R.L.H. 2015. Detection of antibiotic resistance in probiotics of dietary supplements. Nutrition journal, $14(1), 95$.

\section{How to cite this article:}

Uma, A. and Rebecca, G. 2018. Antibiotic Resistance in Bacterial Isolates from Commercial Probiotics Used in Aquaculture. Int.J.Curr.Microbiol.App.Sci. 7(01): 1737-1743. doi: https://doi.org/10.20546/ijcmas.2018.701.210 